\title{
Persebaran Fenomena Suhu Tinggi melalui Kerapatan Vegetasi dan Pertumbuhan Bangunan serta Distribusi Suhu Permukaan
}

\author{
Eggy Arya Giofandi ${ }^{* 1}$ dan Dhanu Sekarjati ${ }^{2}$
}

1,2,3 Program Studi Geografi, Universitas Negeri Padang, Indonesia

\section{Article Info}

\section{Article History}

Dikirim 17 Mei 2020

Diterima 20 Juni 2020

Terbit 29 Juli 2020

\section{Keywords:}

Kota Pekanbaru; suhu tinggi; urbanisasi

Pekanbaru City; high temperature; urbanization

\begin{abstract}
Abstrak
Fenomena suhu tinggi ialah salah satu peristiwa dimana suhu yang ada di wilayah kota lebih panas di bandingkan wilayah sekitarnya. Indonesia terletak di iklim tropis menjadikan beberapa kota berpotensi terjadinya kenaikan suhu pada musim kemarau. Kota Pekanbaru menjadi salah satu merupakan salah satu kota dengan tingkat urbanisasi yang tinggi di Sumatera bagian tengah dengan antusias warga untuk mencari pekerjaan di kota membuat lahan di sekitar kota di jadikan lahan terbangun, kondisi seperti ini menjadikan keberadaan ruang terbuka hijau tidak merata. Tujuan dari penelitian ini memberikan distribusi terjadinya fenomena suhu tinggi melalui pendekatan spatial dengan teknologi penginderaan jauh dan sistem informasi geografi. Penelitian ini menggunakan citra landsat 5 untuk tahun 2000 dan untuk tahun 2009, landsat 8 untuk tahun 2018 dengan metode Land Surface Temperature (LST), Normalized Difference Vegetation Index (NDVI) dan Normalized Difference Built-up Index (NDBI). Hasi dari penelitian menjelaskan Banyaknya bangunan yang ada membuat terjadinya kenaikan suhu di perkotaan dengan suhu awal 29,93oC menjadi 35,54oC. kenaikan suhu terjadi sepanjang tahun dengan puncak terpanas suhu mencapai 37 oC pada 15 April 2013. Sedangkan pada tahun 2009 terjadi penurunan suhu dengan tingkatan berkisar 28,27oC. Kondisi kerapatan vegetasi terjadi penurunan sebesar 0,05 mulai dari 0,66 di tahun 2000 menjadi 0,61 di tahun 2018, hal ini sejalan dengan peningkatan luas bangunan menjadi 15.368 Ha di tahun 2018. Kondisi ini menjadikan Kota Pekanbaru sebagai salah satu kota terpanas yang ada di Indonesia dengan kebutuhan lahan terbangun semakin tinggi serta tingginya mobilitas berpotensi mempercepat perubahan kenaikan suhu sehingga diperlukan ketersediaan ruang terbuka hijau diwilayah padat bangunan dengan membuat ruang terbuka publik dan ruang terbuka privat.
\end{abstract}

\begin{abstract}
The phenomenon of high temperature is one of the events where the temperature in the city area is warmer than the surrounding area. Indonesia is located in a tropical climate, making several cities have the potential for temperature increases during the dry season. Pekanbaru City is one of the cities with a high level of urbanization in central Sumatra, with the enthusiasm of residents looking for work in the city, making the land around the city turned into built-up land, conditions like this make the existence of green open spaces uneven. The purpose of this study is to provide the distribution of the occurrence of high temperature phenomena through a spatial approach with remote sensing technology and geographic information systems. This research uses Landsat 5 imagery for 2000 and for 2009, Landsat 8 for 2018 with the Land Surface Temperature (LST), Normalized Difference Vegetation Index (NDVI) and Normalized Difference Built-up Index (NDBI) methods. The result of the research explains that the number of existing buildings causes an increase in temperature in cities with an initial temperature of $29.93 p C$ to 35.54 oC. temperature increases occur throughout the year with a hot peak of temperature reaching 37 oC on April 15, 2013. Meanwhile, in 2009 there was a decrease in temperature with levels ranging from $28.270 \mathrm{C}$. The condition of vegetation density decreased by 0.05 starting from 0.66 in 2000 to 0.61 in 2018, this is in line with the increase in building area to 15,368 Ha in 2018. This condition makes Pekanbaru City as one of the hottest cities in Indonesia with a higher need for built-in land and high mobility, which has the potential to accelerate changes in temperature so that it requires the availability of green open spaces in densely-built areas by creating public open spaces and private open spaces.
\end{abstract}

(c) 2020 The Authors. Published by UNNES. This is an open access article under the CC BY license (http://creativecommons.org/licenses/by/4.0/)

*E-mail : aryaeggy15@gmail.com

Address : Jl Prof. Dr. Hamka Air Tawar, Padang, Sumatera Barat

DOI 10.15294/jg.v17i2.24486 


\section{PENDAHULUAN}

Pesatnya pembangunan menimbulkan terjadinya dampak negatif yaitu penurunan kualitas lingkungan dan meningkatnya suhu udara dengan berbagai aktivitas perkotaan mulai dari konversi lahan, padat penduduk yang tidak terkendali menjadi pemicu terjadinya peningkatan temperatur suhu udara diwilayah kota dan sekitarnya (Kurniati \& Nitivattananon, 2014). Kondisi ini dinamakan Urban Heat Island. Idealnya, dilihat dengan membandingkan suhu daerah perkotaan dengan wilayah tanpa/sebelum menjadi kota (Magee, Curtis, \& Wendler, 1999).

Secara fisik, perkembangan suatu kota dapat terlihat dari penduduknya yang makin bertambah, keberadaan bangunan yang semakin rapat, dan meningkatnya populasi penduduk terutama pemukiman yang cenderung semakin luas, serta semakin lengkapnya fasilitas kota yang mendukung kegiatan sosial dan ekonomi perkotaan. Kepadatan kota yang lebih tinggi dapat menghasilkan efisiensi keuntungan, tetapi ada interaksi antara yang meningkat risiko efek terjadinya suhu panas perkotaan dan kepadatan yang lebih tinggi, yang perlu dipahami ialah ketika kota ditutupi permukaan dan bahan penyerap panas membuat daerah perkotaan lebih hangat dari pada daerah pedalaman (Sharifi \& Lehmann, 2015). Selain pengaruh dari aktifitas manusia juga menghasilkan panas yang akan memberi efek pada peningkatan suhu, yaitu panas antropogenik. Panas dari aktivitas manusia lebih banyak terjadi di perkotaan karena umumnya memiliki pemukiman, sarana transportasi, dan kawasan industri yang lebih padat daripada di daerah pedesaan (Wicahyani, Sasongko, \& Izzati, 2013).

Perubahan tatanan perkotaan yang terjadi di suatu daerah merupakan dasar dari pertimbangan dalam suatu perencanaan pembangunan perkotaan (Susanti, 2006). Dimana pesatnya perkembangan dan pemekaran telah merubah lansekap kota dengan ruang terbuka hijau di jadikan sarana dan prasarana publik yang berdampak pada perubahan penutupan dan penggunaan lahan. Perubahan penutupan lahan dapat merubah reflektansi radiasi surya permukaan bumi dan menyebabkan pendinginan ataupun pemanasan lokal (Handayani, 2007). Hal ini akan berpengaruh terhadap kondisi kualitas udara, kesehatan, manusia dan juga akan berpengaruh terhadap penggunaan energi yang ada di kota tersebut (U.S. Environment Protection Agency, 2001).

Pemerintah Indonesia telah mengambil langkah cepat dalam menanggapi fenomena urban heat island dengan menerbitkan UU No. 26 Tahun 2007 tentang Penataan Ruang dan Permen PU No.
05/PRT/M/2008 tentang Pedoman Penyediaan dan Pemanfaatan Ruang Terbuka Hijau di Kawasan Perkotaan dengan area Ruang Terbuka Hijau (RTH) memanjang/jalur dan mengelompok yang penggunaannya lebih bersifat terbuka, tempat tumbuh tamanan baik yang tumbuh secara alamiah maupun yang sengaja ditanam. Selain itu Untuk meningkatkan lingkungan termal di sekitar gedung dan mengurangi UHI, disarankan untuk menggunakan bahan absorptivitas lebih rendah, reflektifitas lebih tinggi, dan konduktivitas termal yang lebih besar (Ningrum, 2018).

Kajian mengenai fenomena suhu tinggi penting dilakukan, mengingat terus meningkatnya suhu udara di daerah perkotaan serta dapat menciptakan lingkungan yang tidak nyaman bagi masyarakat, disisi lain mitigasi mengenai dampa fenomena tersebut menjadi salah satu isu utama dalam pembangunan kawasan perkotaan bekelanjutan. Untuk itu tujuan penelitian ini adalah memberikan arahan distribusi UHI melalui teknik penginderaan jauh pada Kota Pekanbaru.

\section{METODE}

Penelitan ini dilaksanakan di Kota Pekanbaru (101 $14^{\prime}-101^{\circ} 34^{\prime} B T$ dan $\left.0^{\circ} 25^{\prime}-0^{\circ} 45^{\prime} L U\right)$. Data yang digunakan adalah citra Landsat 5 path 127 dan row 60 perekaman 7 juli tahun 2000 dan perekaman 16 juli 2009, sedangkan citra Landsat 8 path 127 dan row 60 perekaman 26 agustus tahun 2018. Data diperoleh tidak berbayar dengan mengunduh melalui situs USGS (United States Geological Survey) yaitu www.earthexplorer.usgs.gov. Syarat pemilihan citra menggunakan bulan yang mendekati sama tiap tahunnya dengan tujuan untuk meminimalkan perbedaan musim pada saat perekeman citra serta survei lapangan. Kemudian metode yang digunakan dalam penelitian yaitu Land Surface Temperature digunakan untuk mengetahui suhu permukaan Kota Pekanbaru dengan memanfaatkan kanal band inframerah thermal, kemudian Normalized Difference Vegetation Index digunakan untuk memperoleh informasi mengenai kerapatan vegetasi melalui kanal band infra merah dekat dan kanal band merah, sedangkan Normalized Difference Built-up Index digunakan dalam mengetahui perkembangan lahan terbangun melalui kanal band inframerah pendek dan inframerah dekat. Setelah kondisi suhu permukaan, kerapatan vegetasi, dan bangunan diketahui lalu menghitung luas bangunan menggunakan field calculator. Selanjutnya tingkat kerapatan vegetasi, bangunan, suhu permukaan dilakukan proses overlay untuk mendapatkan keberadaan fenomena suhu tinggi, setelah itu melakukan survei dengan pengambilan 
sampel lokasi fenomna suhu tinggi serta pengamatan terhadap genangan air dan kondisi vegetasi sekitar secara visual.

\section{Suhu Permukaan}

Prinsip dasar yang dikembangkan dalam deteksi suhu udara mengacu kepada prinsip fisika caha pada black body temperature. Pada dasarnya setiap panjang gelombang akan sensitif terhadap respon suhu permukaan yang mempengaruhi nilai pantul objek (Hanif, 2017). Dalam ekstraksi citra landsat $5 \& 7$ umumnya menggunakan kanal band 6 (inframerah termal) untuk mendeteksi suhu permukaan darat. Dimana suhu permukaan diperoleh dengan cara mengkonversi nilai digital kanal 6 (inframerah termal) ke dalam spektral radian menggunakan formula :

(USGS, 2001)

$$
L \gamma=\operatorname{Lmin}+\left\{\left(\frac{\operatorname{Lmax}-L \min }{255}\right) / D N\right\}
$$

Keterangan :

$\mathrm{L} \psi=$ spektral radian $(\mathrm{Wm}-2 \mathrm{sr}-1 \mu \mathrm{m}-2)$

Lmin = spektral radian maksimal untuk kanal 6 (Wm-2sr-1 $\mu \mathrm{m}-2)$.

Lmin kanal 6Low $=0 \mathrm{Wm}-2 \mathrm{sr}-1 \mu \mathrm{m}-2 \mathrm{Lmin}$ kanal 6 High $=3.200 \mathrm{Wm}-2 \mathrm{sr}-1 \mu \mathrm{m}-2$

Lmax = spektral radian maksimum untuk kanal $6(\mathrm{Wm}-2 \mathrm{sr}-1 \mu \mathrm{m}-2)$

Lmax kanal 6Low $=17.04 \mathrm{Wm}-2 \mathrm{sr}-1 \mu \mathrm{m}-2$

Lmax kanal 6 High $=12.650 \mathrm{Wm}-2 \mathrm{sr}-1 \mu \mathrm{m}-2$

(Ket : Lmin dan Lmax diperoleh dari file MTL LS-5_TM)

$\mathrm{DN}=$ nilai digital $(0-255)$

Dengan mengasumsikan emisivitas permukaan adalah satu, maka formula yang digunakan untuk menghitung suhu permukaan adalah :

(USGS, 2002)

$$
T=\frac{K_{2}}{\operatorname{In}\left(\frac{K_{1}}{C V \mathrm{R}_{2}}+1\right)}
$$

Dimana :

Ts = Suhu permukaan (Kelvin)

$\mathrm{K} 1=$ Konstanta kalibrasi $1=666.09(\mathrm{Wm}-2$ sr$1 \mu \mathrm{m}-2)$

K2 = konstanta kalibrasi $2=1282.719$ (Kelvin)

$\mathrm{L} \gamma=$ spektral radian $(\mathrm{Wm}-2 \mathrm{sr}-1 \mu \mathrm{m}-2)$ Untuk mengkonversi nilai suhu permukaan ke dalam ${ }^{\circ} \mathrm{C}$, nilai yang diperoleh dikurangi 273
Sedangkan untuk landsat 8 inframerah thermal terdapat pada band 10 dan band 11, namun band 10 memiliki panjang gelombang 10,60-11,19 $\mu \mathrm{m}$ sedangkan band 11 memiliki panjang gelombang $11,50-12,51 \mu \mathrm{m}$. Umumnya band 10 biasa digunakan untuk mengekstrak pengolahan suhu permukaan darat dengan resolusi spasia 30 meter.

a. DN to Spektral Radian

$$
L \lambda=M L x Q c a l+A L
$$

Keterangan :

$\mathrm{Ml}_{\mathrm{l}}$ = faktor skala

$\mathrm{Al}_{\mathrm{L}}=$ faktor penambah

Qcal = Digital Number $(\mathrm{DN})$

Kemudian setelah digital number tadi di kalkulasikan menjadi radian, selanjutnya nilai spektral radian di konvesi ke suhu kecerahan yang suhu efektif diliat oleh satelit dengan asumsi emisivitas persatuan.

$$
T=\frac{K_{2}}{\operatorname{In}\left(\frac{K_{1}}{C V \mathrm{R}_{2}}+1\right)}
$$

Keterangan :

$\mathrm{T}=$ Suhu (Kelvin)

CVR = Nilai Radian Pada Band Thermal

$\mathrm{K} 1 \& \mathrm{~K} 2=$ Ketetapan

Selanjutnya setelah menghitung nilai suhu pada satuan Kelvin, kami melakukan proses konversi dari Kelvin menjadi Celcius.

$C=K-272.15$

Keterangan :

$\mathrm{C}=$ Celcius

$\mathrm{K}=$ Kelvin

\section{Kerapatan Vegetasi}

Dalam menganalisis tingkat kehijauan vegetasi menggunakan suatu nilai yang memiliki interval tertentu dimana nilai tersebut mempresentasikan tingkatan kerapatan tumbuhan yang dipengaruhi oleh kondisi klorofil terkandung didalam tumbuhan tersebut. Sedangkan fenomena penyerapan cahaya merah oleh klorofil dan pemantulan cahaya inframerah dekat (NIR) oleh jaringan mesofil yang terdapat pada daun akan membuat nilai kecerahan yang diterima sensor satelit pada kedua band tersebut akan berbeda (Ardiansyah, 2015). Hasil yang diperoleh dari indeks kerapatan vegetasi berada pada -1 hingga 1 , saat nilai mende- 
kati -1 menjelaskan tingkat kerapatan vegetasi berupa kawasan tidak bervegetasi kemudian jika nilai indeks kerapatan vegetasi mendekati 1 menandakan kondisi tersebut memiliki tingkat kerapatan yang sangat rapat. Formula yang digunakan untuk menghitung kerapatan vegetasi adalah :

(Rouse et al, 1973)

$$
N D V I=\frac{N I R-R}{N I R+R}
$$

Keterangan :

NDVI = Indeks Vegetasi

NIR = Band Near Infrared

$\mathrm{R}=$ Band Red

Tabel 1. Tingkat Kerapatan Vegetasi

\begin{tabular}{ccc}
\hline No & Nilai NDVI & Tingkat Kerapatan \\
\hline 1 & $-1 \mathrm{~s} / \mathrm{d}-0.32$ & Tidak bervegetasi \\
2 & $-0.32 \mathrm{~s} / \mathrm{d} 0.25$ & Jarang \\
3 & $0.25 \mathrm{~s} / \mathrm{d} 0.42$ & Cukup Rapat \\
4 & $0.42 \mathrm{~s} / \mathrm{d} 0.50$ & Rapat \\
5 & $0.50 \mathrm{~s} / \mathrm{d} 1$ & Sangat Rapat \\
\hline \multicolumn{2}{c}{ Sumber : (Careca, 2013, Modifikasi Hanif, 2016) }
\end{tabular}

\section{Kerapatan Bangunan}

Indeks bangunan ini dikembangkan untuk menonjolkan kenampakan lahan terbangun dibandingkan dengan objek lainnya sehingga mempermudah pemetaan daerah urban. Biasanya dalam melihat perkembangan lahan terbangun menggunakan multi waktu perekaman citra, sehingga dapat diindikasikan perubahan dan penggunaan lahan diperkotaan (Hanif, \& Adenan, 2016). Nilai yang diperoleh dari indeks kerapatan bangunan berada pada -1 hingga 1 , saat nilai mendekati -1 menjelaskan keterangan dalam pixel tersebut tidak terdapat bangunan jika nilai indeks kerapatan bangunan mendekati 1 menandakan kondisi kenampakan tersebut berupa bangunan yang sangat rapat. Formula yang digunakan yaitu :

(Zha, Gao, \& Ni, 2003)

$$
N D B I=\frac{S W I R-N I R}{S W I R+N I R}
$$

Keterangan :

NDBI = Indeks Bangunan

SWIR = Band Short Wave Infrared

NIR = Band Near Infrared
Tabel 2. Tingkat Kerapatan Bangunan

\begin{tabular}{ccc}
\hline No & Nilai NDBI & Tingkat Kerapatan \\
\hline 1 & $<0$ & Tidak Bangunan \\
2 & $0 \mathrm{~s} / \mathrm{d} 0.1$ & Jarang \\
3 & $0.1 \mathrm{~s} / \mathrm{d} 0.2$ & Cukup Rapat \\
4 & $0.2 \mathrm{~s} / \mathrm{d} 0.3$ & Rapat \\
5 & $>0.3$ & Sangat Rapat \\
\hline Sumber : (As-syakur, Adnyana, Arthana, \& Nuarsa, 2012)
\end{tabular}

\section{HASIL DAN PEMBAHASAN}

Kota Pekanbaru mengalami peningkatan suhu yang amat cepat, kondisi persebaran suhu umumnya berlokasi di area padat bangunan dengan tidak ditemukannya vegetasi disekitar bangunan-bangunan yang ada. Peningkatan suhu yang terjadi memberikan efek terhadap sekitarnya terutama saat ditemukan adanya genangan air maka air tersebut akan lebih cepat terjadi penguapan dan kering, jika ditemukan sedikit vegetasi mengakibatkan kondisi vegetasi tersebut menjadi layu dan berpotensi kering hingga mati.

Tabel 3. Data Suhu Permukaan, Kerapatan Vegetasi, dan Bangunan

\begin{tabular}{cccc}
\hline Tahun & Suhu Permukaan & $\begin{array}{c}\text { Kerapatan } \\
\text { Vegetasi }\end{array}$ & Bangunan \\
\hline 2000 & $21,64 \mathrm{~s} / \mathrm{d} 29,93^{\circ} \mathrm{C}$ & $-0,15 \mathrm{~s} / \mathrm{d} 0,66$ & $10.454 \mathrm{Ha}$ \\
2009 & $20,85 \mathrm{~s} / \mathrm{d} 28,27^{\circ} \mathrm{C}$ & $-0,18 \mathrm{~s} / \mathrm{d} 0,65$ & $14.551 \mathrm{Ha}$ \\
2018 & $24,95 \mathrm{~s} / \mathrm{d} 35,54^{\circ} \mathrm{C}$ & $-0,16 \mathrm{~s} / \mathrm{d} 0,61$ & $15.368 \mathrm{Ha}$ \\
\hline
\end{tabular}

Sumber : Hasil Analisis

Tabel 3 Menjelaskan hasil yang ditemukan dari citra satelit keberadaan suhu permukaan kota Pekanbaru mengalami kenaikan mencapai $35,54^{\circ} \mathrm{C}$ tahun 2018. Hal ini sesuai dengan keterangan nilai kerapatan vegetasi dalam kurun waktu 18 tahun terjadi penurunan kerapatan sebesar 0,05 dari tahun 2000 hingga tahun 2018. Sedangkan keberadaan bangunan yang tiap tahun semakin meningkat mengakibatkan tinggi tekanan konversi lahan vegetasi menjadi lahan terbangun untuk memenuhi kebutuhan manusia, pertumbuhan luasan bangunan dalam periode 18 tahun mencapai $4.914 \mathrm{Ha}$ membentuk bangunan perkotaan yang lebih padat. Keterkaitan dari suhu permukaan, kerapatan vegetasi, dan bangunan memberikan dampak terhadap unsur-unsur iklim maupun cuaca yang ada di Pekanbaru, dampak yang paling dirasakan manusia dengan perubahan radiasi dan energi adalah berubahnya temperatur suhu udara. Sedangkan menurut (Arya, 2018) proses konversi lahan dengan perubahan pemanfaatan lahan vegetas menjadi peruntukkan lahan terbangun menyebabkan suhu lebih panas dibandingkan lahan bervegetasi dan 


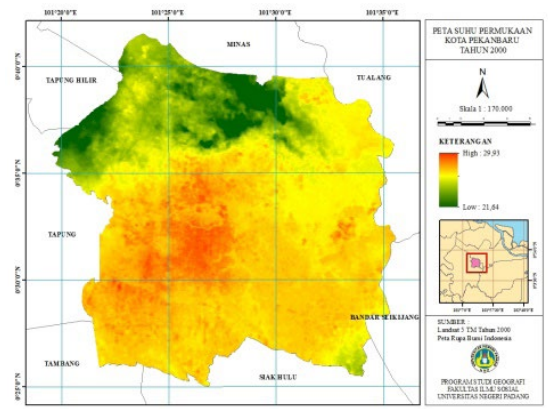

a.

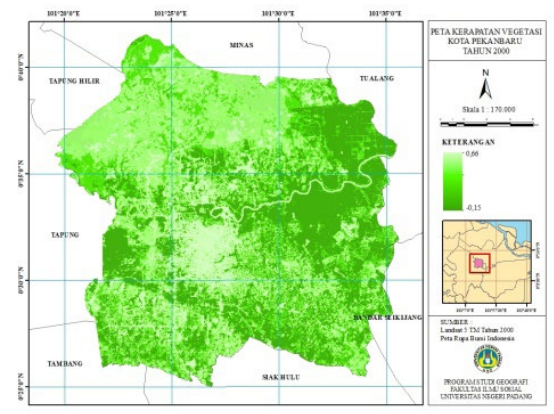

d.

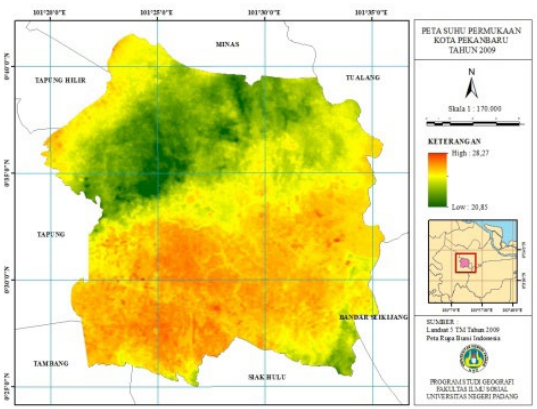

b.

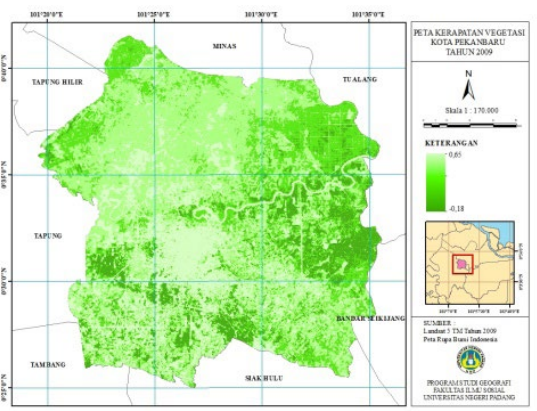

e.

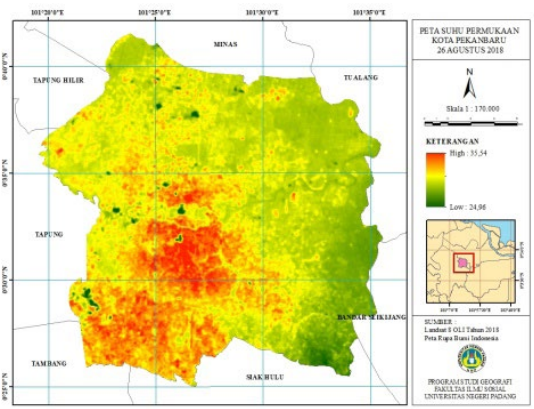

C.

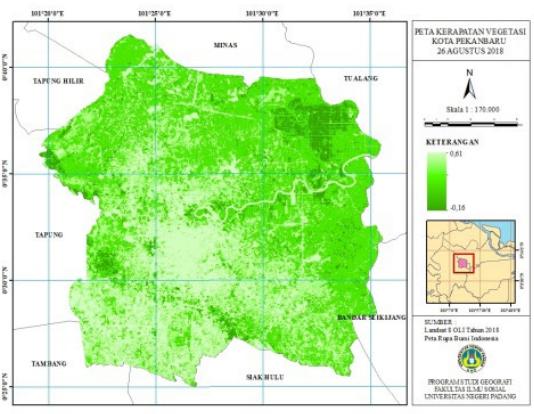

f.

Gambar 1. a. Suhu permukaan tahun 2000 b. Suhu permukaan tahun 2009 c. Suhu permukaan tahun 2018 d. Indeks kerapatan vegetasi tahun 2000 e. Indeks kerapatan vegetasi tahun 2009

f. Indeks kerapatan vegetasi tahun 2018

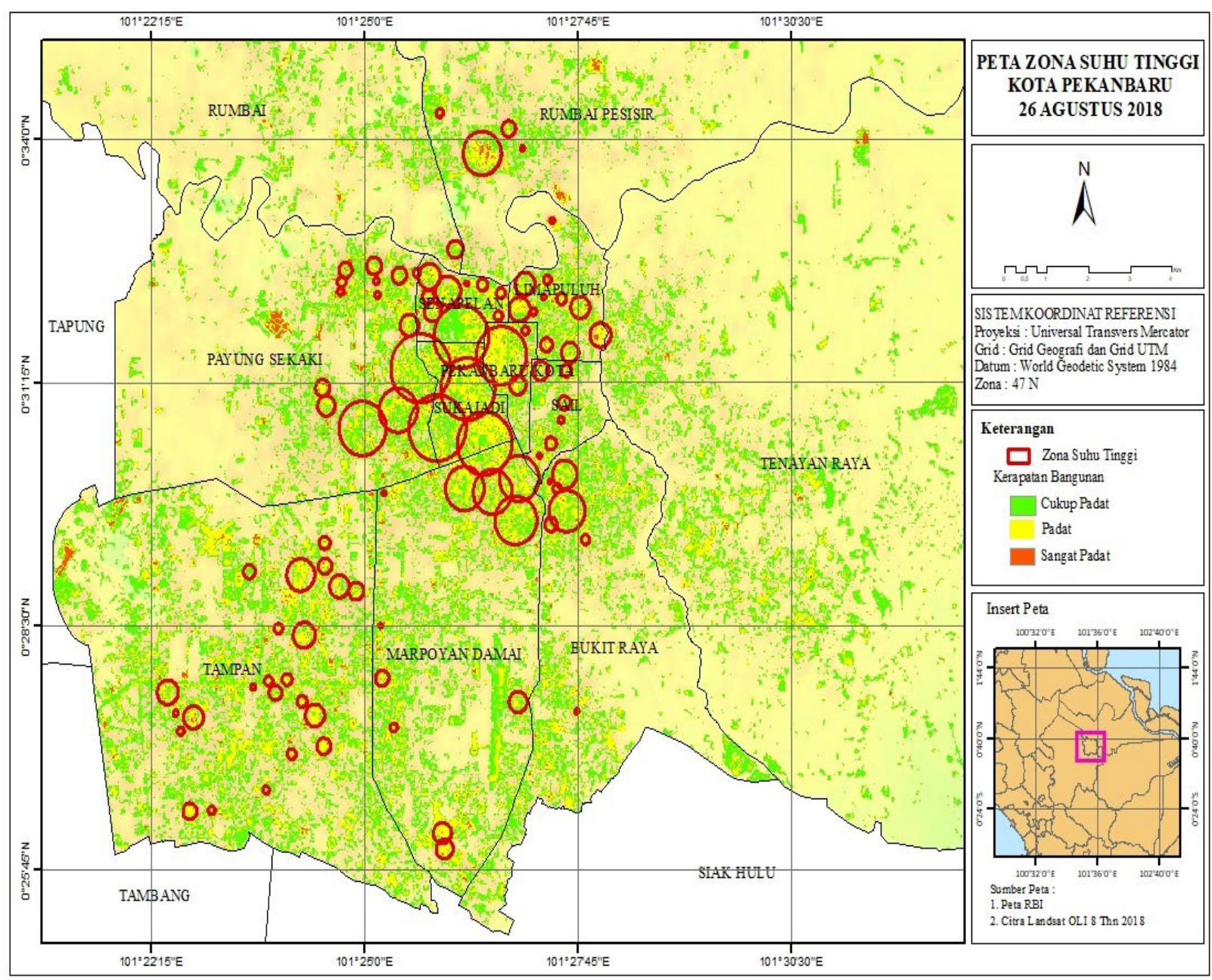

Gambar 2. Peta Zona Suhu Tinggi Kota Pekanbaru 2018 


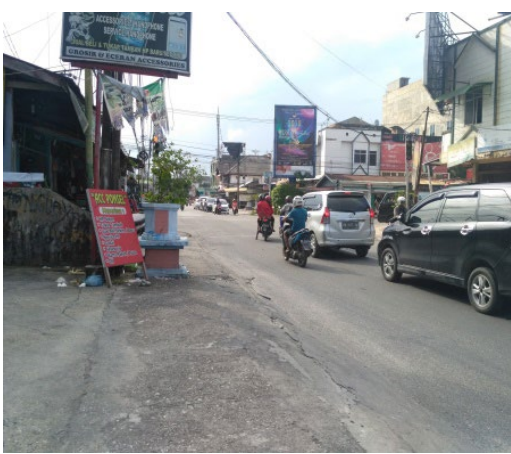

(a)

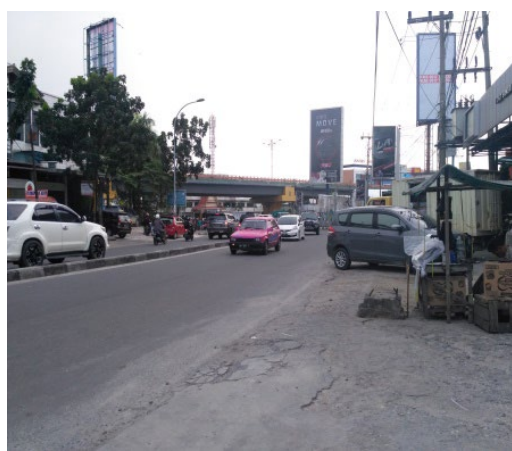

(b)

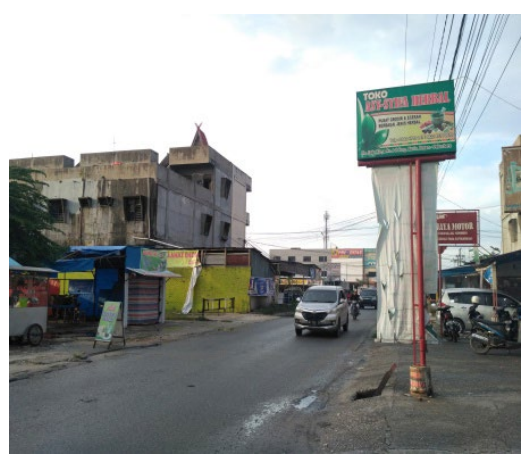

(c)

Gambar 3. (a). Kecamatan Sukajadi (b). Kecamatan Bukit Raya (c). Kecamatan Tampan

sering sekali dicurigai titik hotspot saat dimusim kemarau datang.

Peta zona keberadaan area suhu tinggi dibuat dengan cara overlay hasil olahan Land Surface Temperature, Normalized Different Vegetaion Index, dan Normalized Difference Built-up Index. Kemudian jika keterangan indeks vegetasi tidak bervegetasi, suhu panas, dan kerapatan bangunan sangat padat menghasilkan informasi keberadaan persebaran zona dengan suhu tertinggi pada tahun 2018. Hasil yang termuat dalam peta menampilkan zona-zona suhu tinggi yang berada paling banyak pada kawasan pusat pemerintahan dan pembelanjaan dimana kerapatan pada zona ini didominasi oleh kerapatan bangunan padat hingga sangat padat, kondisi ini juga berada pada zona yang tersebar diluar dari kawasan pusat tersebut seperti di Kecamatan Tampan, pada wilayah ini lahan terbangun mendominasi kerapatan cukup padat hingga padat sehingga minim ketersediaan vegetasi membuat suhu menjadi tinggi pada suatu wilayah memberikan penyinaran matahari terasa lebih panas dari pada wilayah yang lain. Temuan dari analisis ini sesuai dengan pendapat (Tursilowati, 2007) Keadaan geometri perkotaan ini lebih kompleks jika dibandingkan daerah sekitarnya dengan gedung-gedung tinggi didaerah perkotaan menghalangi radiasi panas atmosfer kemudian panas yang tertahan dipancarkan kembali diantara bangunan menjadi simpanan panas dan berpotensi meningkatnya suhu didaerah perkotaan.

Gambar 3 menjelaskan wilayah terjadi suhu tinggi pada perwakilan kecamatan yang ada dengan keberadaan jalan yang tidak adanya vegetasi tertanam, memungkinkan kondisi ini mempercepat pancaran sinar matahari sampai kepermukaan bumi. Kondisi struktur bangunan dan jalan terbuat dari beton, semen, aspal dan besi yang kedap akan sinar matahari menjadikan sekitar wilayah terpusat menghasilkan suhu - suhu tinggi saat disiang hari dan saat musim kemarau datang dengan suhu rata-rata bulanan $27.9^{\circ} \mathrm{C}$ (BPS, 2019). Hal ini seja- lan dengan pernyataan (Sasky, Sobirin, \& Wibowo, 2017) Suhu harian vegetasi variasinya lebih kecil dari pada bangunan beton, karena pada siang hari vegetasi menyerap sinar matahari dalam jumlah besar.

\section{SIMPULAN}

Kota Pekanbaru memiliki peluang terjadinya zona-zona potensial suhu tinggi dibeberapa tahun yang akan datang, dengan kebutuhan lahan terbangun semakin tinggi serta tingginya mobilitas diperkotaan berpotensi mempercepat perubahan kenaikan suhu tersebut. Peningkatan suhu ini mencapai $35,54^{\circ} \mathrm{C}$ dengan ketersediaan vegetasi yang semakin berkurang dilihat dari nilai maksimum kerapatan vegetasi, jika dari hasil kerapatan bangunan mulai tahun 2000 hingga tahun 2018 menemukan pertumbuhan luas bangunan awal $10.454 \mathrm{Ha}$ mencapai $15.368 \mathrm{Ha}$. Banyaknya ditemukan bangunan tanpa ada vegetasi disekitar membuat terjadinya kenaikan suhu. Namun untuk memperkecil efek fenomena suhu tinggi diperlukan vegetasi untuk mengembalikan fungsi alam diwilayah perkotaan serta penerapan ruang terbuka hijau bangunan/ bangunan beratap hijau agar menjadi solusi yang dapat diambil dalam mengatasi efek pemanasan global pada kawasan padat akan bangunan.

\section{DAFTAR PUSTAKA}

Ardiansyah. (2015). Pengolahan Citra Penginderaan Jauh Menggunakan ENVI 5.1 dan ENVI LiDAR.

Arya, E, \& Nizam, K. (2018). Terapan Data Landsat Dalam Pemantauan Sebaran Titik Panas dan Distribusi Temperatur Dalam Mitigasi Bencana Kebakaran Hutan dan Lahan (Studi Kasus Pulau Bengkalis, Riau). Prosiding Simposium Nasional Penginderaan Jauh, Institute Teknologi Sumatera, 2018.

As-syakur, A. R., Adnyana, I. W. S., Arthana, I. W., \& Nuarsa, I. W. (2012). Enhanced built-UP and bareness index (EBBI) for mapping built-UP and bare land in an urban area. Remote Sensing, 4(10), 2957-2970. https:// doi.org/10.3390/rs4102957.

Badan Pusat Statistik Kota Pekanbaru, (2019). Kota Pekanbaru Dalam Angka Tahun 2019. Pekanbaru : Badan Pusat Statistik. 
Handayani. (2007). Identifikasi perubahan kapasitas panas kawasan perkotaan dengan menggunakan citra Landsat TM/ ETM (studi kasus : Kota Bogor). Skripsi. Jurusan Geofisika dan Meteorologi. FMIPA IPB, Bogor.

Hanif, Muhammad. (2016). Studi Perubahan Kerapatan Vegetasi Catchment Area Danau Maninjau Dengan Teknologi Penginderaan Jauh dan Sistem Informasi Geografi. Skripsi. Geografi. Universitas Negeri Padang.

Hanif, Muhammad., Adenan Yandra. (2016). Hubungan Lahan Terbangun Perkotaan Dengan Fenomena Iklim Mikro Urban Heat Island.

Hanif, M. (2017). Aplikasi Citra Satelit Digital.

Kurniati, A. C., \& Nitivattananon, V. (2014). 3rd AASIC : Sustainable Development of Asian Community STRATEGIES FOR MITIGATING URBAN HEAT ISLAND EFFECTS IN SURABAYA, INDONESIA in Surabaya Based on Significant Factors Influencing. 32-36.

Magee, N., Curtis, J., \& Wendler, G. (1999). The urban heat island effect at Fairbanks, Alaska. Theoretical and Applied Climatology, 64(1-2), 39-47. https://doi.org/10.1007/ s007040050109.

Ningrum, W. (2018). Urban Heat Island towards Urban Climate. IOP Conference Series: Earth and Environmental Science, 118(1). https://doi.org/10.1088/17551315/118/1/012048.

Peraturan Menteri Pekerjaan Umum Nomor : 05/ PRT/M/2008. Tentang Pedoman Penyediaan dan Pemanfaatan Ruang Terbuka Hijau di Kawasan Perkotaan.

Sasky, P., Sobirin, \& Wibowo, A. (2017). Pengaruh Perubahan Penggunaan Tanah Terhadap Suhu Permukaan Daratan Metropolitan Bandung Raya Tahun 2000 -
2016. Industrial Research Workshop and National Seminar, 8(July), 354-361.

Sharifi, E., \& Lehmann, S. (2015). Correlation analysis of surface temperature of rooftops, streetscapes and urban heat island effect: Case study of central Sydney. Journal of Urban and Environmental Engineering, 9(1), 3-11. https://doi.org/10.4090/juee.2015.v9n1.003011

Susanti, I. (2006). Aspek Iklim dan Perencanaan Tata Ruang. Jurnal PPI Edisi Vol 8 No.17 November 2006. LAPAN : Jakarta.

Tursilowati, L. (2007). Use of Remote Sensing and Gis To Compute Temperature Humidity Index As Human Comfort Indicator Relate With Land Use-Land Cover Change ( Lulc ) in Surabaya. The 73rd International Symposium on Sustainable Humanosphere, (July), 160-166.

U.S. Environment Protection Agency. 2001. Heat Island Effect. EPA Global Warming Actions Local Heat Island Effect. U.S. EPA.

U.S. Global Change Research Program. 2001. Our Changing Planet. A Suplement to the President's Fiscal Year 2002 budget.

Undang Undang Republik Indonesia No.26 Tahun 2007. Tentang Penataan Ruang.

Wicahyani, S., Sasongko, S. B., \& Izzati, M. (2013). Pulau Bahang Kota ( Urban Heat Island ) Di Yogyakarta Hasil Interpretasi Citra Landsat Tm Tanggal 28 Mei 2012. Prosiding Seminar Nasional Pengelolaan Sumberdaya Alam Dan Lingkungan 2013, 289-294.

Zha, Y., Gao, J., \& Ni, S. (2003). Use of normalized difference built-up index in automatically mapping urban areas from TM imagery. International Jour- 